\title{
Technology Crowdfunding in Russia: Alternative Finance for Start-ups
}

Submitted on 17/12/18, $1^{\text {st }}$ revision 22/1/19, $2^{\text {nd }}$ revision 4/2/19 accepted 28/3/19

Dmitrii Ilenkov ${ }^{1}$,

\begin{abstract}
:
Purpose: Crowdfunding has proved to be an effective way for many technology start-ups worldwide to start or grow their businesses. One of the largest crowdfunding platforms in the world, Kickstarter, claims to have over 700 million dollars pledged to succesfully funded projects. Russian crowdfunding market is relatively smaller in size, but can as well provide another source of alternative finance for technology start-ups.

Design/Methodology/Approach: In this article, we analyse empirically the major factors that contribute to technology projects success in crowdfunding. Exploring 832 technology projects posted on two most popular Russian crowdfunding platforms, we use correlation and cluster analysis to highlight the factors explaining fundraising success over failure.

Findings: Our results show that an increase in the project funding goal is correlated with a lower probability and extent of success.

Practical Implications: Our findings suggest that crowdfunding may play a vital role in financing for a rather limited number of Russian technology start-ups, since the average amounts funded are still too small to be significant for most start-ups.

Originality/Value: Issues for further research and discussion are identified including successful and failed projects attributes and backers' motivation.
\end{abstract}

Keywords: Crowdfunding, crowd technologies, entrepreneurial finance, alternative finance, Russia, technology, startups.

JEL Classification: G29.

Acknowledgement: This work is supported by the Russian Science Foundation under grant №17-78-10190

Paper type. Research article.

${ }^{1}$ Financial University under the Government of the Russian Federation, dailenkov@fa.ru 


\section{Introduction}

Emerging businesses commonly called start-ups tend to be flexible, open to changes and experiments, and so they are sometimes considered as a great place for innovative technologies to arise (Riedl, 2013). At the same time, we have to admit that the potential of these enterprises is often limited by the access to stable financing, especially early-stage financing, which has crucial impact on new ventures success (Gompers and Lerner, 2004; Kortum and Lerner, 2000). The risk and uncertainty associated with new projects often restricts for start-ups an opportunity to raise funds from venture foundations, business angels and other traditional methods of financing. This situation motivates newborn enterprises to seek for alternative ways of funding associated with crowdsourcing such as crowdfunding, crowd-investing and crowdsale.

Crowdfunding can be described as the practice of raising funds for the projects by receiving rather small amounts of money from a possibly large number of backers, most often using specially created for that purpose online platforms. This comparatively new mechanism of attracting capital to projects began to gain popularity during the financial crisis of 2008-2009 and continued its expansion to the Russian market in 2012.

The history of Kickstarter with its most ever-funded projects and especially Indiegogo with its broad opportunities for entrepreneurs shows that crowdfunding may become a useful source of finance particularly for technology projects in Russia, where mostly crowdfunding platforms Boomstarter and Planeta.ru create opportunities for technology start-ups. Although the Russian Government claims SME's support and development to be one of the high-priority policy directions, there are still many obstacles appear in case the new company tries to attract investments and crowdfunding can be a good alternative source of funding for start-ups.

With the scope, we suggest analysis of crowdfunding for technological projects in Russia, as it seems to be a relatively easy and popular alternative way to gain funds for technological start-ups. We present the continuation of the empirical study on 9.179 crowdfunding projects (Ilenkov and Kapustina, 2018), with an emphasis on 832 technology projects. Finally, we discuss the findings and draw some implications for research and practice.

\section{Literature Review}

Different aspects of barriers start-ups meet seeking financing from traditional sources are studied by such authors as Carpenter and Petersen (2002), Cassar (2004), RupeikaApoga et al. (2018), Thalassinos and Thalassinos (2018), Schwienbacher and Larralde (2010). Ang (1991) and Agrawal et al. (2010) suggest friends and family can help start-ups collect some funding, while other authors consider founders' savings as a source of finance. 
A large contribution to crowdfunding projects research was made by Mollick (2013) exploring the underlying dynamics of success and failure among crowdfunded ventures, Schwienbacher and Larralde (2010), paying attention to crowdfunding of small entrepreneurial ventures. Kuppuswamy and Bayus (2015), studied backer dynamics over the project funding cycle. The reasons entrepreneurs launch crowdfunding campaigns are explored by Belleflamme et al. (2010) and Gerber et al. (2011). Crowdfunding cases of technology start-ups seeking funds are investigated by Cordova, Dolci and Gianfrate, (2013).

In Russia, an empirical study of the Russian crowdfunding platforms was made by Ilenkov and Kapustina (2018). An overview of general conditions for start-up financing through crowdfunding was partly described by Sedelnikov (2015) and Mechik (2015). The work by Saltykov and Gordeev (2016) presents a statistical analysis of Technology, Game and Design categories, conducted for Russian crowdfunding platforms Boomstarter and Planeta.ru, and compared to the Kickstarter. More research and discussions, especially on financing SME's through crowdtechnologies, can be found in the publications of Gruzina, Zeinalov, and Ilenkov (2016 and 2017). The present research will contribute to the above-mentioned cases in terms of technological crowdfunding projects with a deeper analysis.

\section{Research methods}

The dataset we use in this research contains 832 cases of technology crowdfunding projects from 2014 to 2018 . As we mentioned above, technology crowdfunding can become an important source of capital investments for new innovative enterprises. Data is extracted from Planeta and Boomstarter, the two most popular crowdfunding platforms in Russia. The dataset represents the state of technology crowdfunding in Russia and provides enough projects to be analysed.

Our dataset provides us information, including the total amount of funds contributed by investors (which we will call funded), the initial amount of funds required by the project founders (goal), the number of backers who invested in the project (backers). Using this original data, we calculated the average amount backers provided for a project (average contribution) and percentage of the original goal founders managed to gather (success rate).

To determine major factors explaining success of the projects we implemented correlation and cluster analysis. Notice that, the analysis is limited to reward-based projects.

\section{Results}

\subsection{Descriptive statistics}


Technology projects make up one of the most popular categories on Russian crowdfunding platforms with $9 \%$ of all the projects launched. The data in Table 1 shows that while being very popular for launching projects this category at the same time shows a significantly smaller share of pledges gathered.

Table 1. Technology projects share in total projects

\begin{tabular}{|l|l|l|l|}
\hline & Technology & All projects & Share \\
\hline Projects & 832 & 9179 & $9 \%$ \\
\hline Funded & 39662674 & 649884509 & $6 \%$ \\
\hline Backers & 23204 & 386617 & $6 \%$ \\
\hline
\end{tabular}

Source: Developed by author.

Further analysis presented in Table 2, shows that technology projects not only gather less money than the average, but they are also not so popular among the backers and do not show high rates of success. On the contrary, average goal for technology project is higher than total average.

Table 2. Comparing technology projects with average

\begin{tabular}{|l|l|l|}
\hline & Technology & All projects \\
\hline Goal average & 696816 & 488277 \\
\hline Funded average & 47671 & 70801 \\
\hline Average pledge & 1709 & 1681 \\
\hline Backers average & 28 & 42 \\
\hline Rate of success & $10 \%$ & $13 \%$ \\
\hline
\end{tabular}

Source: Developed by author.

Table 3 shows descriptive statistics for the most significant variables we have investigated in our analysis. According to Table 1, only $10 \%$ of the 832 projects have been totally successful, which means that the project founders managed to gain at least $100 \%$ of the goal. At the same time, while the mean of the success rate, measuring the magnitude of the funded (the total investment received by a given project) with respect to the amount of goal (funds requested) by each crowd founder in percentage terms, is relatively higher; this is because some projects have been highly successful, as it can be seen from the maximum value of the success rate (one project has obtained an amount of investment about 4 times higher than the initial goal). The number of backers can range from a minimum of 0 to a maximum of 3.451, the mean amount contributed by each funder (mean contribution) moves in a range that goes from 1.200 Russian rubles to 150.225 Russian rubles with mean of 7.560 Russian rubles.

Table 3. Descriptive statistics

\begin{tabular}{|l|l|l|l|l|l|}
\hline Variable & Objects & Mean & $\begin{array}{l}\text { Standart } \\
\text { deviation }\end{array}$ & Min & Max \\
\hline Goal & 832 & 696815,5 & 1252763 & 2000 & 15733689 \\
\hline
\end{tabular}




\begin{tabular}{|l|l|l|l|l|l|}
\hline Funded & 832 & 47671,48 & 210507,3 & 0 & 2195843 \\
\hline Success Rate & 832 & 0,137306 & 0,413966 & 0 & 4,1841667 \\
\hline Backers & 832 & 27,88942 & 178,5278 & 0 & 3451 \\
\hline Average contribution & 832 & 1200,908 & 7560,65 & 0 & 150225 \\
\hline
\end{tabular}

Source: Developed by author.

\subsection{Correlation matrix}

Bivariate analysis is useful for analyzing whether two variables are related or not. The goal is to discover whether there are any significant relationships between the dependent variable and the independent variables.

The significant correlation coefficients obtained through Pearson's correlation test represents the relationship between the variables. We have to state that a relationship between the two variables does not guarantee that changes in one variable are a direct cause of changes in the other. There may have been more invisible variables. So, to summarize, there may be cause-and-effect between the variables, but the correlation level does prove cause.

Table 4. Correlation matrix

\begin{tabular}{|l|l|l|l|l|l|}
\hline & Goal & Funded & Backers & $\begin{array}{l}\text { Success } \\
\text { rate }\end{array}$ & $\begin{array}{l}\text { Average } \\
\text { contribution }\end{array}$ \\
\hline Goal & 1,00 & 0,07 & 0,04 & $-0,09$ & $-0,02$ \\
\hline Funded & & 1,00 & 0,71 & 0,69 & 0,19 \\
\hline Backers & & & 1,00 & 0,42 & 0,01 \\
\hline Success rate & & & & 1,00 & 0,25 \\
\hline $\begin{array}{l}\text { Average } \\
\text { contribution }\end{array}$ & & & & & 1,00 \\
\hline
\end{tabular}

Source: Developed by author.

According to the results, there is no or negligible relationship between higher project goal and the amount funded or number of backers, moreover, there is even slight negative relation between higher project goal and success rate.

\subsection{Cluster analysis}

To check this hypothesis, we divided all projects into 5 groups by the amount of goal as shown in Table 5. Near half of the project authors aim to get from 100.000 to 500.000 rubles, while the least popular group are projects trying to get up to 50.000 Russian rubles. Projects with most humble goals, aiming to have less than 50.000 Russian rubles, make up $6 \%$ of all the projects. 
Table 5. Technology projects grouped by original goal

\begin{tabular}{|l|l|l|}
\hline Over 1 000 000 Russian rubles & 152 & $18 \%$ \\
\hline From 500 000 to 1000000 Russian rubles & 147 & $18 \%$ \\
\hline From 100 000 to 500 000 Russian rubles & 397 & $48 \%$ \\
\hline From 50 000 to 100 000 Russian rubles & 84 & $10 \%$ \\
\hline To 50 000 Russian rubles & 52 & $6 \%$ \\
\hline Total & 832 & $100 \%$ \\
\hline
\end{tabular}

Source: Developed by author.

The most successful category, as shown in Table 6 , are the smallest projects with goals under 50.000 rubles - the success rate for these projects is $31 \%$. The least successful category are projects with goals beyond 1.000 .000 rubles - the average success rate for these projects is $8 \%$, and the average amount of funds those projects usually get is less than 100.000 rubles - at least 10 times less than the initial goal, which makes those initial goals look quite unrealistic in general.

Projects with a goal from 500.000 to 1.000 .000 rubles have the largest number of average backers -47 , even larger than among those, trying to get over 1.000 .000 rubles -34 . It supports our previous findings meaning that potential backers generally tend to support projects with more realistic goals.

Table 6. Technology projects grouped by original goal-descriptive statistics

\begin{tabular}{|l|c|l|l|l|l|}
\hline Funded & $\begin{array}{l}\text { Over } \\
1000000 \\
\text { rubles }\end{array}$ & $\begin{array}{l}\text { From } \\
500000 \text { to } \\
1000000 \\
\text { rubles }\end{array}$ & $\begin{array}{l}\text { From } \\
100000 \text { to } \\
500000 \\
\text { rubles }\end{array}$ & $\begin{array}{l}\text { From 50 000 } \\
\text { to 100 000 } \\
\text { rubles }\end{array}$ & $\begin{array}{l}\text { to 50 000 } \\
\text { rubles }\end{array}$ \\
\hline $\begin{array}{l}\text { Average } \\
\text { backers }\end{array}$ & 34 & 47 & 18 & 8 & 8 \\
\hline $\begin{array}{l}\text { Maximum } \\
\text { backers }\end{array}$ & 2713 & 3451 & 634 & 79 & 70 \\
\hline $\begin{array}{l}\text { Average } \\
\text { contribution }\end{array}$ & 838 & 1260 & 1550 & 469 & 613 \\
\hline Success rate & $8 \%$ & $11 \%$ & $15 \%$ & $14 \%$ & $31 \%$ \\
\hline $\begin{array}{l}\text { Average } \\
\text { funded }\end{array}$ & 96654 & 71894 & 33321 & 9632 & 7023 \\
\hline
\end{tabular}

Source: Developed by author.

To check our findings, we calculated the actual percentage of initial goal the projects managed to get, considering the initial goal size - see details in Table 7.

Projects aiming to raise less than 50.000 rubles are most overfunded $-19 \%$ of projects managed to get more than $100 \%$ of funds initially requested. For projects with goal over 1.000 .000 rubles is only $3 \%$ of projects with overfunding. 
The same situation is about projects, which were $75 \%$ and more funded - the most successful were those with lower targets $-19 \%$ for projects with goals up to 50.000 rubles and $4 \%$ for those, aiming to get at least 1.000 .000 .

The most interesting finding comes when we look at projects, which got $0 \%$ support. $26 \%$ of "million" projects didn't get a single ruble from the backers. It may mean that those projects often have no trust from potential backers at all. The same rate for projects, aiming to get less than 50.000 is $17 \%$, which is much closer to normal $-14 \%$ of Russian crowdfunding projects never get a ruble as we found out in our recent research.

Table 7. Technology projects grouped by original goal - rate of success

\begin{tabular}{|l|l|l|l|l|l|}
\hline Funded & $\begin{array}{l}\text { Over } 1000 \\
000 \text { rubles }\end{array}$ & $\begin{array}{l}\text { From 500 } \\
\text { 000 to } 1000 \\
000 \text { rubles }\end{array}$ & $\begin{array}{l}\text { From } 100 \\
000 \text { to 500 } \\
000 \text { rubles }\end{array}$ & $\begin{array}{l}\text { From 50 000 } \\
\text { to } 100000 \\
\text { rubles }\end{array}$ & $\begin{array}{l}\text { to 50 000 } \\
\text { rubles }\end{array}$ \\
\hline $\begin{array}{l}\text { Over } \\
100 \%\end{array}$ & $3 \%$ & $6 \%$ & $9 \%$ & $7 \%$ & $19 \%$ \\
\hline $\begin{array}{l}\text { Over } \\
75 \%\end{array}$ & $4 \%$ & $6 \%$ & $9 \%$ & $8 \%$ & $19 \%$ \\
\hline $\begin{array}{l}\text { Over } \\
50 \%\end{array}$ & $5 \%$ & $9 \%$ & $10 \%$ & $12 \%$ & $25 \%$ \\
\hline $\begin{array}{l}\text { Over } \\
25 \%\end{array}$ & $5 \%$ & $11 \%$ & $12 \%$ & $14 \%$ & $27 \%$ \\
\hline 0 & $26 \%$ & $19 \%$ & $23 \%$ & $36 \%$ & $17 \%$ \\
\hline
\end{tabular}

Source: Developed by author.

\section{Summary and conclusions}

The paper has a variety of uses, not only because of the depth of analysis, but also because of the lack of quantitative research in this area. Our general findings showed that crowdfunding by its nature is capable to become a new intermediary ground for technology related product development. It may be a potential new ground for early stage entrepreneurial finance to support innovations in future, but as for now only few crowdfunding projects in Russia have gained funds enough to exploit the idea into a sustainable business.

As our research showed, goals over 1.000.000 rubles seem unrealistic; too often they do not get any support at all and too seldom the get overfunded, the average success rate is $8 \%$. On the other hand, small projects with goals less than 50.000 rubles are generally more successful, they are much more often over-funded, and the average success rate is $31 \%$. The question is whether 50.000 rubles is enough to accomplish any project goals and help the founders create a product.

This study provides basic evidence that Russian backers generally prefer to support projects that have more humble goals rather than those looking for big money, sufficient to provide any results. 


\section{References:}

Agrawal, A., Catalini, C., Goldfarb, A. 2010. The Geography of Crowdfunding. SSRN Electronic Journal.

Ang, J.S. 1991. Small business uniqueness and the theory of financial management. The Journal of Small Business Finance, 1(1), 1-13.

Belleflamme, P., Lambert, T., Schwienbacher, A. 2012. Crowdfunding: Tapping the Right Crowd. SSRN eLibrary.

Boomstarter. 2018. What is Boomstarter? Available at: https://boomstarter.ru/help/faq/vvedenie_v_boomstarter\#topic-1.

Carpenter, R.E. and Petersen, B.C. 2002. Is the growth of small firms constrained by internal finance? The Review of Economics and Statistics, 84(2), 298-309.

Cassar, G. 2004. The Financing of Business Start-ups. Journal of Business Venturing, 19, 261-283.

Central Bank of the Russian Federation. 2017. Federal Law Project About Alternative means of investment gaining (crowdfunding). Available at: http://www.cbr.ru/analytics/standart_acts/others/20180125_02.pdf.

Cordova, A., Dolci, J. and Gianfrate, G. 2015. The determinants of crowdfunding success: evidence from technology projects. Procedia - Social and Behavioral Sciences, $181,115-124$.

Cordova, A., Dolci, J. and Gianfrate, G. 2013. The Bearable Lightness of Crowdfunding: Evidences from Technology Projects, 4th European Conference on Corporate R\&D and Innovation CONCORDi-2013, September 26-27, Seville, Spain.

Gompers, P. \& Lerner, J. 2004. The Venture Capital Cycle.

Gruzina, Yu.M., Zeinalov A.A. and Ilienkov, D.A. 2016. Analysis of national and foreign expertise in applying crowdtechnologies in the context of activating project and investment activity of small and middle-sized businesses. Innovations and investment, 10, 8-10.

Gruzina, Yu.M., Zeinalov A.A., Ilienkov, D.A. and Ilienkova, N.D. 2016. Crowdinvesting as a Perspective Instrument of Financing Small and Middle-Sized Businesses in the Russian Federation. Journal of Applied Economic Sciences, XI, 8(46), 1650-1660.

Gruzina, Y.M., Zeinalov, A.A., Ilienkova, N.D., Ilienkov, D.A, Kapustina V.F., Khachaturyan, K.E. 2017. Crowdinvesting: Modern system of organization and financing of projects. Monography, Rusience, $168 \mathrm{p}$.

Hornuf, L. and Cumming, D. 2018. The Economics of Crowdfunding. Palgrave Macmillan, $283 \mathrm{p}$.

Kappuswamy, V. and Bayus, B. 2015. Crowdfinding Creative Ideas: The Dynamics of Project Backers in Kickstarter.

Kickstarter Statistics. 2018. Available at: https://www.kickstarter.com/help/stats.

Kortum, S., Lerner, J. 2000. Assessing the contribution of venture capital to innovation. RAND Journal of Economics, 31, 674-680.

Larionov, N.A. 2014. Crowdfunding as a venture investments tool. Modern mechanisms of social and corporate finance development, Saratov, 144-149.

Massolution. 2013. Crowdfunding Industry Report. Available at: http://reports.crowdsourcing.org/index.php?route=product/product\&path=0\&prod uct_id=58.

Mechik, S. 2015. Crowdfunding as a method of attracting funding to start-up. Economics and Entrepreneurship, 12(4), 45-60. 
Ministry of Economic Development of the Russian Federation. 2018. The crowdfunding law project will be corrected according to market interests, Available at: http://economy.gov.ru/minec/about/structure/depino/201819031.

Mollick, E. 2013. The Dynamics of Crowdfuding: determinants of success and failure. SSRN Electronic Journal. Forthcoming as The Dynamics of Crowdfuding: an exploratory study. Journal of Business Venturing.

Riedl, J. 2013. Crowdfunding technology innovation. IEEE Computer Society.

Rupeika-Apoga, R., Zaidi, H.S., Thalassinos, E.Y. \& Thalassinos, I.E. 2018. Bank Stability:

The Case of Nordic and Non-Nordic Banks in Latvia. International Journal of

Economics \& Business Administration, 6(2), 39-55.

Planeta.ru 2018. Crowdfunding Platform Statistics. Available at: https://planeta.ru/about.

Saltykov, B. and Gordeev, M. 2016. Crowdfunding as a tool of venture investments in Russia and abroad, Innovations, 4(210), 40-46.

Schwienbacher, A. and Larralde, B. 2010. Crowdfunding of small entrepreneurial ventures. In D.J. Cumming, ed. The Oxford Handbook of Entrepreneurial Finance. Oxford: Oxford University Press.

Sedelnikov, S. 2015. Crowdfunding as a tool for startup financing in the Russian Federation. Modern Economics Issues.

Thalassinos, I.E., Thalassinos, Y. 2018. Financial Crises and e-Commerce: How Are They Related. Available at SSRN: https://ssrn.com/abstract=3330169. 